5. По законодательству обеих стран неустойкой является определённая денежная сумма.

$* * *$

1. $\quad$ Гражданский кодекс Российской Федерации. Часть первая: федер. закон от 30.01.1994 № 51-Ф3 (ред. от 09.03.2021) // Собрание законодательства РФ. 1994. №32.

2. Брагинский, М.И., Витрянский, В.В. Договорное право. Общие положения 3-е изд., стереотипное. / М.И. Брагинский, В.В. Витрянский. М.: Статут, 2001. 476 с.

3. Гонгало, Б.М. Обеспечение исполнения обязательств / Б.М. Гонгало. М.: Спарк, 1999. 152 с.

4. Гришин, Д.А. Неустойка: теория, практика, законодательство / Д.А. Гришин. М.: Статут, 2005.171 c.

5. Ван, Хайянь. Поручительство в системе способов обеспечения исполнения обязательств в КНР и России: сравнительно-правовое исследование: автореф. дис. ... канд. юрид. наук / Ван Хайянь. М., 2006. 32 c.

6. Гражданский кодекс КНР. Принят на 3-ем заседании ВСНП 13-го созыва 25.03.2020. Вступил в силу с 1.01.2021. Часть третья. Гл. 8. Ст. 585, 588. -. [Электронный ресурс]. Офиц. сайт ВСНП KHP. URL: http://www.npc.gov.cn/npc/c30834/202006/75ba6483b8344591abd07917e1d25cc8.shtml

7. Постановление Пленума Верховного Суда РФ от 24.03.2016 N 7 (ред. от 07.02.2017) "О применении судами некоторых положений Гражданского кодекса Российской Федерации об ответственности за нарушение обязательств".

8. Второе разъяснение к закону «О договорах» Верховного народного суда КНР. [Электронный peсурс]. Офиц. сайт ВСНП КНP. URL: http://www.npc.gov.cn/zgrdw/npc/xinwen/fztd/sfjs/200905/14/content_1502093.htm

\title{
Кондратьева В.А.
}

\section{Основные подходы к разграничению договорной и деликтной ответственности в сфере зашиты прав потребителей}

Дальневосточный федеральный университет (Россия, Владивосток)

doi: $10.18411 / 1 j-07-2021-84$

\section{Аннотация}

В настоящей статье рассматривается соотношение договорной и деликтной ответственности в сфере защиты прав потребителей на доктринальном, законодательном и практическом уровнях. Описываются основные подходы к разграничению договорной и деликтной ответственности, а также анализируется проблема конкуренции исков в сфере защиты прав потребителей.

Ключевые слова: гражданско-правовая ответственность, виды ответственности, договорная ответственность, деликтная ответственность, конкуренция исков, защита прав потребителей, недостатки товаров.

\section{Abstract}

This article examines the relationship between contractual and tort liability in the field of consumer protection at the doctrinal, legislative and practical levels of analysis. The main approaches to the differentiation of contractual and tort liability are described, and the problem of competition of claims in the field of consumer protection is analyzed.

Keywords: civil liability, types of liability, contractual liability, tort liability, competition of claims, consumer protection, defects in goods.

Гражданско-правовая ответственность - это обеспеченное государственным принуждением возложение предусмотренных законом или договором лишений имущественного характера на лицо, совершившее неправомерное действие.

Гражданско-правовую ответственность по основаниям возникновения и содержанию разделяют на договорную и внедоговорную (деликтную). 
Исследование проблемы разграничения деликтной и договорной ответственности в сфере защиты прав потребителей имеет не только теоретический, но и практический интерес, так как анализ норм действующего законодательства позволяет выявить пробелы в законодательстве и найти пути их решении.

Необходимость решения вопроса о разграничении договорной и деликтной ответственности обуславливается сложностью определения сферы применения каждой из видов ответственности, уяснения условий возложения в каждом конкретном случае того или иного вида ответственности, а также обозначения объема и особенностей деликтной и договорной ответственности, то есть для разрешения конкретных вопросов, связанных с тем или иным видом ответственности.

Разграничение договорной и деликтной ответственности, прежде всего приобретает практический интерес в тех случаях, когда деликт является и нарушением договорного обязательства.

В сфере защиты прав потребителей доминирующим видом ответственности является договорная ответственность, так как отношения между потребителем и продавцом, изготовителем, исполнителем возникают вследствие заключения договора, в случае нарушения положений договора наступает ответственность (договорная).

Вместе с тем, закон также предусматривает наступление имущественной ответственности за вред, причиненный вследствие недостатков товара (работы, услуги) (ст. 14 Закона РФ от 07.02.1992 № 2300-1 «О защите прав потребителей»)(далее - Закон РФ «О защите прав потребителей»), то есть деликтную ответственность. Данный вид ответственности возникает независимо от наличия между сторонами договорных отношений.

В данном случае, необходимо рассмотреть вопрос относительно возможности возникновения конкуренции исков (договорного и деликтного) в рассматриваемой сфере при продаже товаров (выполнении работ, оказании услуг) ненадлежащего качества. Российское законодательство не предусматривает возможности применения конкуренции исков, в связи с чем необходимо четко разграничить договорную и деликтную ответственность.

Таким образом, актуальность исследования обусловлена повышением потребности граждан в качественных товарах, работах и услугах; стремительным развитие современного рынка товаров, работ и услуг различного качества, что в свою очередь порождает увеличение появления некачественных товаров, работ и услуг и как следствие необходимость эффективной защиты прав потребителей.

В настоящее время в отечественной и зарубежной доктрине существует три основных подхода к пониманию проблемы разграничения договорной и деликтной ответственности.

Первый подход к пониманию проблемы основывается на единой правовой природе гражданско-правой ответственности, в рамках которой договорная и деликтная различаются исключительно в применяемых правовых режимах. Согласно данной теории возможна конкуренция исков, а также гражданин вправе основываясь исключительно на своих собственных убеждениях (а не на природе факта нарушения его права), выбирать способ защиты (договорной, внедоговорной).

Вторая позиция представляет собой юридическую конструкцию единого требования о возмещении вреда. В рамках данной теории всеобщая обязанность не причинять вред лицу и его имуществу и договорная обязанность рассматриваются как идентичные по содержанию, так как договорная обязанность хоть и возникает вследствие заключения договора, но основывается, так или иначе прежде всего на законе. В рамках данной теории договорная ответственность представляет собой элемент, входящий в состав единого требования о возмещении вреда. 
Содержание третьей теории заключается в том, что важен исключительно факт возникшего вреда по вине причинителя, при этом неважно какое противоправное действие послужило основанием для причинения вреда.

Согласно данной теории не допускается дифференциации требований, у гражданина всегда должно быть одно требование, которое в зависимости от обстоятельств дела должно квалифицироваться либо только как договорное, либо только как деликтное.

Рассматриваемые виды ответственности в сфере защиты прав потребителей могут быть предусмотрены условиями договора, нормами общей части Гражданского кодекса Российской Федерации (далее - ГК РФ), нормами ГК РФ о соответствующих видах договоров, нормами Ф3 «О защите прав потребителей».

Договорная ответственность, в случае ее наступления (нарушение договорного обязательства сторонами) регулируется нормами главы 25 ГК РФ.

Так, например, при продаже товара ненадлежащего качества у покупателя возникает ряд прав, в число которых входит в том числе его право потребовать от продавца возмещения причиненных убытков (ст. 393 ГК РФ). Данное право носит договорный характер и реализуется в рамках договора купли-продажи.

Нормы о внедоговорной ответственности применяются в том случае, когда соответствующая санкция применяется к правонарушителю, не состоящему в договорных отношениях с потерпевшим, либо в связи с совершением деликта даже в том случае, когда стороны находятся в договорных отношениях.

Так, параграфом 3 главы 59 ГК РФ регулируются отношения по возмещению вреда, причиненного вследствие недостатков товара, работы или услуги, то есть деликтная ответственность.

Такая ответственность возлагается независимо от вины, а также от наличия договорных отношений между сторонами. Главное требование состоит в том, что услуга приобреталась гражданином в потребительских целях.

Вышеназванные положения также закреплены в пункте 35 Постановления Пленума Верховного Суда РФ от 28.06.2012 № 17 «О рассмотрении судами гражданских дел по спорам о защите прав потребителей».

В соответствии со ст. 1096 ГК РФ вред, причиненный вследствие недостатков товара, подлежит возмещению по выбору потерпевшего продавцом или изготовителем товара.

Кроме того, данная норма резюмирует, что вред, причиненный вследствие недостатков работы или услуги, подлежит возмещению лицом, выполнившим работу или оказавшим услугу (исполнителем), а вред, причиненный вследствие не предоставления полной или достоверной информации о товаре (работе, услуге), подлежит возмещению всеми вышеуказанными лицами.

В силу п. 2 ст. 14 Закон РФ «О защите прав потребителей» право требовать возмещения вреда, причиненного вследствие недостатков товара (работы, услуги), признается за любым потерпевшим независимо от того, состоял он в договорных отношениях с продавцом (исполнителем) или нет.

Так, например, в случае возгорания бытовой техники, вследствие которого пострадало имущество не только лица, которое эту технику приобрело, но и посторонних людей (например соседей), право на возмещение вреда будут иметь и иные лица, а не только лицо непосредственно купившее данный товар.

Кроме того, в случае если потерпевших несколько, каждый из них сам решает, от кого - от продавца или изготовителя - потребовать возмещения причиненного вреда.

Существует мнение, что ст. 1096 ГК РФ предусматривает возможность конкуренции исков в российском праве тем, что предоставляет потерпевшему право выбора к кому предъявлять иск (к продавцу или изготовителю товара). 
Вместе с тем, в частности и судебная практика показывает, что данная статья не предусматривает конкуренции исков, так как речь идет только о выборе ответчика, но не о выборе основания иска, которое в любом случае будет внедоговорным (даже при наличии между сторонами договорных отношений).

Так в процессе анализа судебной практики однозначно видно, что истец, подает исковое заявление (сфера защиты прав потребителей), которое направлено на привлечение истца к ответственности по договору либо же к ответственности вследствие причинения вреда.

Кроме того, поскольку спорящие стороны состоят в одном правоотношении, а спор возникает по поводу определенного его нарушения, речь может идти лишь о единственном иске.

Выбор договорного или внедоговорного способа защиты необходимо связывать не с инициативой заявителя, а с основанием возникновения ответственности.

Возможность предоставления истцу права выбора между различными основаниями иска может повлечь возникновение рисков, связанных с неправильным установлением тех юридических фактов, исходя из которых суд должен установить действительные отношения сторон и применить к ним надлежащую норму закона. Предоставление истцу возможности выбора вида иска, исходя из своих собственных предубеждений приведет к затягиванию сроков судопроизводства, так как рассмотрение дела будет направлено по «ложному» пути.

Кроме того, с процессуальной точки зрения, правовая квалификация спорного правоотношения является задачей суда, однако при этом суд не связан позицией истца по делу.

Дискуссии в отношении данной нормы все же возникают, на мой взгляд, в силу того, что в ст. 1096 ГК РФ четко не указано, что именно подразумевается под выбором и при неправильно ее толковании могут возникнуть определённые сомнения.

В данном случае, чтобы исключить неправильное толкование ст. 1096 ГК РФ, в нее следует внести изменения, добавив положение, в котором будет содержаться указание на то, что потерпевшему предоставлено право выбора исключительно субъекта, к которому он может предъявить свои требования.

Критерии разграничения деликтной и договорной ответственности в сфере защиты прав потребителей выделяются только на доктринальном уровне.

Российское законодательство при этом не содержит прямого запрета на конкуренцию исков, но исходя из анализа норм права, а также судебной практики можно сделать вывод об отсутствии конкуренции исков.

Данное несоответствие законодательного и практического уровней уровню доктринальному порождает различные разногласия среди ученых и практиков в отношении рассматриваемого вопроса соотношения видов ответственности в сфере защиты прав потребителей, а также, что не менее важно создает трудности для потребителей, права которых были нарушены тем или иным образом.

Таким образом, проведенный анализ соотношения договорной и деликтной ответственности в сфере защиты прав потребителей позволяет сделать следующие выводы.

Во-первых, деликтная и договорная ответственность имеют каждая свою специфику, но вместе с тем, являясь видами гражданско-правовой ответственности, имеют общие признаки, что порождает необходимость в их разграничении.

Во-вторых, проблемы разграничения вышеназванных видов ответственности возникают при причинении вреда сторонам, состоящим в договорных отношений. Разграничение стоит проводить по основанию возникновения ответственности.

В-третьих, конкуренцию исков российское законодательство не предусматривает, на практике она также отсутствует, но вместе с тем, существует неоднозначное толкование ряда норм, которые определяют ответственность в сфере 
зашиты прав потребителей. Но все же однозначно можно сказать, что такая категория как конкуренция исков усматривается преимущественно на доктринальном уровне.

В-четвертых, наличие предусмотренной законом альтернативной возможности обращения с иском к продавцу или изготовителю нельзя рассматривать как конкуренцию исков, поскольку потерпевшему предоставляется выбор не между основаниями к возмещению вреда, а, всего лишь, между субъектами возмещения.

1. Гражданский кодекс РФ (часть вторая) 26.01.1996 г. № 14-Ф3// Собр. Законодательства Рос. Федерации. 1996. № 5. Ст. 410. (ред. от 09.03.2021) - Доступ из СПС «КонсультантПлюс». Текст: электронный.

2. О защите прав потребителей: Закон РФ от 07.02.1992 года № 2300-1// Ведомости СНД и ВС РФ. 09.04.1992. № 15. ст. 766. (ред. от 22.12.2020) - Доступ из СПС «КонсультантПлюс». - Текст: электронный.

3. О рассмотрении судами гражданских дел по спорам о защите прав потребителей: Постановление Пленума Верховного Суда РФ от 28.06.2012 № 17. - Доступ из СПС «КонсультантПлюс». Текст: электронный.

4. Гражданское право: учебник // под ред. Б. М. Гонгало. М.: Статут, 2017. С. 315.

5. Анохин А.А. Основные континентальные воззрения на соотношение договорной и деликтной ответственности. [Электронный ресурс] // Юридическая наука. 2020. URL: https://cyberleninka.ru/article/n/osnovnye-kontinentalnye-vozzreniya-na-sootnoshenie-dogovornoy-ideliktnoy-otvetstvennosti. Загл. с экрана. (дата обращения 23.03.2021).

6. Мамин А.С., Халин Р.В. Сравнительно-правовой анализ разграничения договорной и деликтной ответственности за вред, причиненный вследствие недостатков товаров, работ или услуг по действующему законодательству РФ. [Электронный ресурс] // Проблемы экономики и юридической практики. 2013, URL: https:/cyberleninka.ru/article/n/sravnitelno-pravovoy-analizrazgranicheniya-dogovornoy-i-deliktnoy-otvetstvennosti-za-vred-prichinennyy-vsledstvienedostatkov.Загл. с экрана. (дата обращения 29.03.2021).

7. Маркова О.А. Соотношение договорной и деликтной ответственности в сфере защиты прав потребителей / О.А. Маркова // Право и экономика. 2010. № 9. - Доступ из СПС «КонсультантПлюс». - Текст: электронный.

\section{Котова Н.Н., Руденко 3.Ш. \\ Актуальные вопросы языка права в профессиональной подготовке юристов}

Крымский филиал ФГБОУВО «РГУП»

(Россия, Симферополь)

doi: $10.18411 / 1 j-07-2021-85$

\section{Аннотация}

В статье показана роль русского языка в подготовке будущих юристов, подчеркнута особенность устной речи как основы деловой компетенции профессионала. В будущей деятельности юристу необходимо овладеть терминологией права, нормами русского литературного языка, поскольку это язык общения и по роду занятий юрист должен выступать в роли оратора, грамотно оформлять процессуальные документы, владеть навыками диалогового способа ведения беседы, учитывая психологические особенности собеседников. Кроме этого подчеркиваются некоторые проблемы, с которыми сталкиваются преподаватели права и русского языка.

Ключевые слова: язык права, терминология, русский язык, процессуальные документы, коммуникативно-речевые навыки, вуз, профессионализм, юрист, законодательство.

\section{Abstract}

The article shows the role of the Russian language in the training of future lawyers, emphasizes the peculiarity of oral speech as the basis of a professional's business competence. In the future, a lawyer needs to master the terminology of law, the norms of the Russian 